\title{
Caracterización epidemiológica de las áreas endémicas de estomatitis vesicular en México (1981-2012)
}

\section{Epidemiological characterization of vesicular stomatitis in Mexico (1981-2012)}

\author{
Roberto Navarro Lópeza, Lauro Velázquez Salinasb, Susana Arellano Chávezc, I rene \\ López Gonzáleza, César Luis Villarreal Cháveza, J uan Antonio Montaño Hirosea
}

\begin{abstract}
RESUMEN
El presente estudio se diseñó para mejorar el sistema de vigilancia de las enfermedades vesiculares en México, bajo el sistema de planeación estratégica, identificando las zonas endémicas a través de la estabilidad de linajes virales del serotipo Nueva Jersey, y analizando epidemiológicamente la información generada en 32 años de vigilancia e investigación. Se presentan los resultados que permitieron caracterizar epidemiológicamente las áreas donde se mantiene el virus de estomatitis vesicular de manera secular en México, y con ello, los componentes necesarios para la construcción de la Matriz de Indicadores para Resultados (MIR) para el programa de vigilancia de las enfermedades vesiculares en México, que pueden también servir para otros países afectados por esta enfermedad. Adicionalmente se aportan elementos para la prevención de la enfermedad, así como mejorar el comercio internacional de animales de países endémicos de estomatitis vesicular.
\end{abstract}

PALABRAS CLAVE: Linajes, Exportación de caballos, Vectores, Estomatitis vesicular, MI R.

\begin{abstract}
The present study aims to improve the surveillance system of vesicular diseases in Mexico, using the strategic planning system, by identifying endemic areas in which the New Jersey serotype viral lineages are stable and by analyzing the information generated during $32 \mathrm{yr}$ of monitoring. The study shows the necessary elements for building the Matrix of Results Indicators (MRI) that could be used on the vesicular diseases surveillance program in Mexico and in other affected countries. The results that allowed the characterization of the epidemiological areas where the virus of vesicular stomatitis (VS) remains in a secular way in Mexico are presented. Elements for disease prevention are also provided in order to improve the live animal international trade.
\end{abstract}

KEY WORDS: Vesicular stomatitis, Horse export, Endemic stomatitis, Vectors.

\section{INTRODUCCIÓN}

En México, la estomatitis vesicular (EV) es una enfermedad endémica transmisible, de notificación inmediata obligatoria a las autoridades de salud animal por su importancia estratégica y por sus efectos en la producción pecuaria y comercio internacional(1). Las

\section{INTRODUCTION}

In Mexico, the vesicular stomatitis (VE) is a transmissible endemic disease, mandatory of immediate notification to the authorities of animal health by its strategic importance and its effects on livestock production and international trade(1). The greatest losses in

\footnotetext{
a Servicio Nacional de Sanidad, Inocuidad y Calidad Agroalimentaria / Dirección General de Salud Animal. Avenida Municipio Libre 377 , Piso 7 Ala B, Col. Santa Cruz Atoyac, Deleg. Benito Juárez. 03310, México DF. México. clvillarrealch02@yahoo.com.mx Correspondencia al quinto autor.

b USDAIRS Plum Island Animal Disease Center, Greenport, NY. USA.

c Universidad Autónoma de Chiapas. Tuxtla Gutiérrez, Chiapas, México.
} 
mayores pérdidas en producción se presentan en brotes fuera de las zonas endémicas $(2,3)$. La Organización Mundial de Sanidad Animal (OIE) la retiró de las enfermedades de importancia económica en el año 2014(4). Sin embargo, la Unión Europea (UE) mantiene sus restricciones en el comercio de animales provenientes de países infectados(5). La EV es causada por un virus del género Vesiculovirus de la familia Rhabdoviridae, orden Mononegavirales. Se identifican dos serotipos, denominados Nueva Jersey (NJ) e Indiana (IN)(2,6). El serotipo NJ es responsable del $90 \%$ de los casos dínicos $(2,7)$ identificándose por primera vez en 1947, en el estado de Aguascalientes durante la epizootia de fiebre aftosa (FA) $(8,9,10)$. Se reconoce que ambos serotipos $\mathrm{NJ}$ e IN se mantienen de manera endémica en múltiples linajes virales, en reservorios desconocidos ubicados en diversas zonas tropicales del continente americano, y que ambos son responsables de la presentación anual de casos clínicos fuera de las zonas endémicas $(11,12)$. Existen diversas hipótesis para explicar este fenómeno, la más sólida plantea que se debe al movimiento de vectores $(2,12,13)$. En el serotipo $\mathrm{NJ}$, por medio de análisis filogenéticos, se han reconocido seis clados, siendo el clado I el que abarca los virus circulantes en Norteamérica incluyendo México $(2,12)$, asimismo, se han logrado identificar escapes del clado II de Centroamérica en el centro y sur de México(12). Para el virus IN, se reconocen dos clados, los virus mexicanos se comparten con los identificados en los de USA(2).

La EV es una arbovirosis; los vectores incriminados son las moscas areneras Lutzomias spp (Diptera, Psychodidae) $(14,15,16)$ y las moscas negras Simulidos spp (Díptera: Simulidae) $(3,17)$, en las que se ha comprobado experimentalmente transmisión horizontal y transovárica $(2,14,17)$. Otras especies de vectores pueden estar involucradas $(18,19)$. Se ha planteado que los virus de EV afectan primariamente a los insectos y que ocasionalmente infectan a los mamíferos(20). La EV afecta de manera clínica a los bovinos, porcinos y equinos, sin embargo, production occur in outbreaks outside endemic areas $(2,3)$. The world Organization for Animal Health (OIE) withdrew it from diseases of economic importance in 2014(4). However, the European Union maintains its restrictions on animals trade from infected countries(5). The VE is caused by a virus of the genus Vesiculovirus of the Rhabdoviridae family, order Mononegavirales. Two serotypes, called New Jersey (NJ) and Indiana (IN) are indentified $(2,6)$. The NJ serotype is responsible for $90 \%$ of clinical cases $(2,7)$ identified for the first time in 1947 in the State of Aguascalientes during the outbreak of foot and mouth disease $(F M D)(8,9,10)$. It is recognized that both serotypes $\mathrm{NJ}$ and IN remain endemic in multiple viral lineages, in unknown reservoirs located in various tropical areas of the American continent, and that both are responsible for the annual presentation of clinical cases outside endemic areas $(11,12)$. There are several hypotheses to explain this phenomenon, the most solid states that it is due to the motion of vectors $(2,12,13)$. In the serotype $\mathrm{NJ}$, through phylogenetic analyzes, have been recognized six clades, with the clade I covering the virus circulating in North America including Mexico (2,12); it has also been identified leaks of clade II in Central America and in the Center and South of Mexico(12). For the IN virus, two clades are recognized, Mexican viruses are shared with those identified in the USA(2).

The EV is an arbovirus; the incriminated vectors are the flies sand quarries Lutzomias spp (Diptera, Psychodidae) $(14,15,16)$ and the black flies, Blackflies spp (Diptera: Simulidae) $(3,17)$, in which has been experimentally found horizontal and transovarian transmission $(2,14,17)$. Other vector species may be involved $(18,19)$. It has been suggested that VE viruses primarily affect insects and occasionally infect mammals(20). The VE clinically affects bovine, swine and horses, however, there are subclinical infections detected by serology in a wide range of animal species $(2,21)$. In humans, it is considered one minor zoonosis(22) and is not recognized in its carrier state $(23,24)$. The virus 
existen infecciones subclínicas que se detectan por serología en una amplia gama de especies animales $(2,21)$. En humanos, es considerada una zoonosis menor(22) y no se reconoce que exista el estado de portador(23,24). El virus se transmite por vía transcutánea o transmucosa(17), y los animales afectados clínicamente presentan vesículas en labios, lengua, encías, narinas, pezones, banda coronaria y espacio interdigital de las pezuñas, pudiendo afectar al $90 \%$ de los animales expuestos(25). Estos elementos se utilizan como indicador para la vigilancia de la FA. Ambas enfermedades son indistinguibles clinicamente, por lo que la vigilancia de enfermedades vesiculares es de alta prioridad, considerando, que una baja en la sensibilidad del programa de vigilancia, puede ocasionar que no se detecte oportunamente la FA.

El presente estudio fue diseñado para caracterizar epidemiológica y molecularmente las áreas endémicas de $\mathrm{EV}$ y con ello, generar los Indicadores y la línea base necesarios para la construcción de la Matriz de Indicadores para Resultado (MIR)(26) a fin de coadyuvar a mejorar el sistema de vigilancia de las enfermedades vesiculares en México.

\section{MATERIALES Y MÉTODOS}

Los registros de casos presentados de EV corresponden a bases de datos de la Dirección General de Salud Animal, del Servicio Nacional de Sanidad, Inocuidad y Calidad Agroalimentaria (SENASICA), generados por la Comisión México - Estados Unidos para la Prevención de la Fiebre Aftosa y otras Enfermedades Exóticas de los Animales (CPA) durante 32 años, en el período 1981 a 2012. Esta información contiene datos epidemiológicos y geográficos. Se incluye información generada en los proyectos de colaboración entre Agricultural Research Senvice - United States Department of Agriculture (ARS - USDA) y CPA-SENASICA 2000 - 2004, no publicados, cuyo objetivo principal fue caracterizar las zonas endémicas de EV en México, donde se obtuvieron registros precisos de cada investigación por enfermedad vesicular is transmitted via transcutaneous and transmucosal(17), and clinically affected animals present vesicles on lips, tongue, gums, nostrils, nipples, coronary band and interdigital space of the hooves, and can affect $90 \%$ of the exposed animals(25). These items are used as an indicator for the surveillance of the FMD. Both diseases are clinically indistinguishable, so vesicular disease surveillance is of high priority, whereas a low sensitivity of the surveillance program, can cause it to not timely detect FMD.

The present study was designed to characterize epidemiological and molecularly endemic areas of VE and thus, to generate indicators and a base line necessary for the construction of the Outcome Indicators Matrix (OIM) (26) in order to contribute to improve the surveillance system of vesicular diseases in Mexico.

\section{MATERIALS AND METHODS}

The records of VE cases submitted correspond to databases of the General Directorate of Animal Health of the National Service of Health, Inocuity and Food Quality (SENASICA, by the Spanish name), generated by the Mexico - United States Commission for the prevention of Food and Mouth Disease and other exotic diseases of animals (CPA) for $32 \mathrm{yr}$, in the period 1981 to 2012. This information indudes geographical and epidemiological data. Includes information generated in collaborative projects among Agricultural Research Service - United States Department of Agriculture (ARS - USDA) and CPA-SENASICA 2000 - 2004, unpublished, whose main objective was to characterize the endemic areas of EV in Mexico. Accurate records of each research by vesicular disease were obtained in the States of Chiapas, Tabasco, South of Veracruz, and the Isthmus of Oaxaca. The total of records in this project were 207 research herds confirmed with VE (310 animals average/ research).

The epidemiological study is descriptive(27), with official information from SENASICAs confirmed cases, where a confirmed VE case, comes from 
en los estados de Chiapas, Tabasco, el sur de Veracruz y el Istmo de Oaxaca. El total de registros en este proyecto fueron 207 investigaciones en hatos confirmados con EV (310 animales promedio/investigación).

El estudio epidemiológico es descriptivo(27), con información oficial de SENASICA de los casos confirmados, donde caso confirmado de EV, es una explotación pecuaria en la que se ha demostrado en animales enfermos la presencia del virus de EV, mediante una prueba oficial de muestras de epitelios y líquidos vesiculares, procesados por las técnicas de fijación de complemento y aislamiento viral (hasta 2005). A partir de 2006, por las técnicas de ELISADAS (Double Antibody Sandwich) y RT-PCR.

La serología positiva no es confirmatoria de un caso, los resultados de laboratorio de los sueros sanguíneos reportados en este estudio, fueron producto de las investigaciones en los hatos infectados de EV analizados por la técnica de seroneutralización.

El análisis estadístico se realizó con el programa SPSS for Windows Versión 15.0, SPSS Inc, Chicago III, USA, 2006, para el cálculo de proporciones y desviaciones estándar.

Para generar indicadores estratégicos y una línea base para el programa de vigilancia de las enfermedades vesiculares, se utilizó la guía propuesta por la Secretaria de Hacienda y Crédito Público y otros(26).

Se calculó la Incidencia de EV por 100 mil bovinos, considerando todos los casos por cada año. El algoritmo utilizado fue IEV = (CCEV/PT) 100,000 , donde IEV es igual a la incidencia de la estomatitis vesicular en el año t, CCEV es igual al número de casos confirmados de estomatitis vesicular en el año, y PT es igual a la población total de bovinos en el año $t$.

Para determinar si la densidad animal influye en la persistencia viral, se calculó la proporción $(P)$, que es el número de casos confirmados de EV por año, dividido entre el número de hatos a livestock farm in which the presence of VE virus in sick animals has been demonstrated by an official test of epithelium and vesicular fluid samples, processed by complement fixation and viral isolation techniques until 2005. From 2006, by ELISA-DAS (Double Antibody Sandwich) and RT-PCR techniques.

Positive serology was not confirmatory of a case, laboratory results of blood sera reported in this study were the result of investigations in VE infected herds analyzed by serum neutralization technique.

The statistical analysis was performed with the SPSS program for Windows Version 15.0, SPSS Inc, Chicago III, Inc, USA, 2006, for proportions and standard deviations calculations.

To generate strategic indicators and a baseline for the surveillance program of vesicular diseases, the guidance given by the Ministry of Finance and other was used(26).

Incidence of EV by 100 thousand bovines were calculated, considering all cases each year. The algorithm used was IVE = (CCVE/PT) 100,000, where IVE is equal to the incidence of vesicular stomatitis in year $t, C C V E$, is equal to the number of confirmed cases of vesicular stomatitis in the year, and PT is equal to the total population of bovine animals in the year $t$.

To determine whether the animal density influences the viral persistence, it was calculated the proportion $(P)$, which is the number of confirmed cases of VE per year, divided by the number of herds of cattle in each State (according to the INEGI) multiplied by 10,000(28).

To determine the spatial location of VE cases by climate type, information developed by Köppen was used $(29,30)$. In this classification, climate Af is warm humid with rains throughout the year, Am is warm humid with rains in summer, and Aw warm sub-humid with summer rainfall. Statistical and rainfall data were obtained in the official sites of the National Institute of 
de bovinos en cada entidad federativa de acuerdo al INEGI (28) multiplicado por 10 mil.

Para determinar la ubicación espacial de los casos de EV por tipo de clima, se usó la desarrollada por Köppen(29,30). En esta clasificación, el clima Af corresponde a cálido húmedo con lluvias todo el año, Am corresponde a cálido húmedo con lluvias en verano, y Aw cálido sub-húmedo con lluvias en verano. Los datos estadísticos y de precipitación pluvial se obtuvieron en los sitios oficiales del Instituto Nacional de Estadística y Geografía(28), la Comisión Nacional del Agua(31) y la Secretaría de Medio Ambiente y Recursos Naturales(32).

Con la finalidad de describir la variabilidad genética del virus de estomatitis vesicular serotipo Nueva Jersey en México, por ser el de mayor prevalencia, se realizó el análisis filogenético de 27 cepas (Cuadro 1), todas ellas disponibles en la base de datos de secuencias genéticas del NIH (National Institute of Health de los EUA) conocida como GenBank. Estas cepas se colectaron entre 1982 y 2004 de bovinos en los estados de Chiapas $(n=15)$, Tabasco $(n=$ 4) y Veracruz $(n=8)$ y fueron secuenciadas previamente por otros autores $(33,34,35)$. Para el análisis filogenético se utilizaron 408 nucleótidos que forman parte de la región hipervariable del gen $\mathrm{P}$ del virus EV. Esta región del genoma tiende a acumular una gran cantidad de mutaciones a lo largo del tiempo, y puede reflejar lo que sucede en otras partes del genoma, por lo que ha sido usada en trabajos de caracterización filogenética $(33,34,35)$.

El análisis filogenético se llevó a cabo con el software MEGA 5.03(36). Los parámetros de reconstrucción filogenética incluyen máxima verosimilitud como método de reconstrucción filogenética(37), Tamura de 3 parámetros con distribución gamma(38) como método de substitución nucleotídica, y como soporte estadístico se utilizaron 100 réplicas del método de Bootstrap(39). Adicionalmente, con la finalidad de calcular la diversidad genética total y por Estado, utilizando el software Mega 5.03, se
Statistics and Geography (28), the National Water Commission(31) and the Secretariat of Environment and Natural Resources(32).

In order to describe the genetic variability of the vesicular stomatitis virus serotype New Jersey in Mexico, by being the most prevalent, the phylogenetic analysis of 27 strains was analyzed (Table 1), all of which are available in the database of genetic sequences from the $\mathrm{NIH}$ (National Institute of Health in the United States) known as GenBank. These strains were

Cuadro 1. Cepas de virus de estomatitis vesicular Nueva Jersey utilizadas para describir la diversidad genética del virus en México

Table 1. Strains of vesicular stomatitis virus New Jersey used to describe the genetic diversity of the virus in Mexico

\begin{tabular}{lcccc}
\hline & GenBank & Collection & Year & Reference \\
\hline Strain & EF453239.1 & Chiapas & 2003 & 1 \\
NJ1003CPB & EF453 & 2004 & 1 \\
NJ0704CPB5 & EF453272.1 & Chiapas & 2003 & 1 \\
NJ03CPB1 & EF453296.1 & Chiapas & 2004 & 1 \\
NJ0704CPB3 & EF453245.1 & Chiapas & 2004 \\
NJ0704CPB & EF453244.1 & Chiapas & 2004 & 1 \\
NJ0803CPB2 & EF453228.1 & Chiapas & 2003 & 1 \\
NJ1103CPB & EF453304.1 & Chiapas & 2003 & 1 \\
NJ0789CPB4 & AF252238.1 & Chiapas & 1989 & 2 \\
NJ1296CPB & AF252251.1 & Chiapas & 1996 & 2 \\
NJ0703CPB & EF453246.1 & Chiapas & 2003 & 1 \\
NJ1096CPB2 & AF252245.1 & Chiapas & 1996 & 2 \\
NJ0704CPB6 & EF453247.1 & Chiapas & 2004 & 1 \\
NJ0704CPB2 & EF453299.1 & Chiapas & 2004 & 1 \\
NJ0803CPB3 & EF453290.1 & Chiapas & 2003 & 1 \\
NJ0903CPB & EF453298.1 & Chiapas & 2003 & 1 \\
NJ1003TBB & EF453225.1 & Tabasco & 2003 & 1 \\
NJ1203TBB & EF453242.1 & Tabasco & 2003 & 1 \\
NJ1203TBB2 & EF453224.1 & Tabasco & 2003 & 1 \\
NJ1103TBB2 & EF453226.1 & Tabasco & 2003 & 1 \\
NJ0589VCB & AF252232.1 & Veracruz & 1989 & 2 \\
NJ0296VCB & AF252230.1 & Veracruz & 1996 & 2 \\
NJ00VCB2 & EF453293.1 & Veracruz & 2000 & 1 \\
NJ00VCB4 & EF453227.1 & Veracruz & 2000 & 1 \\
NJ1103VCB & EF453300.1 & Veracruz & 2003 & 1 \\
NJ0997VCB & AF252243.1 & Veracruz & 1997 & 2 \\
NJ1182VCB2 & M31867.1 & Veracruz & 1982 & 3 \\
NJ1103VCB3 & EF453295.1 & Veracruz & 2003 & 1 \\
\hline & & & & \\
\hline
\end{tabular}


realizaron comparaciones pareadas entre las secuencias tomando en cuenta el número de diferencias nucleotídicas.

\section{RESULTADOS}

Análisis de la información 1981-2012

El total de casos confirmados de EV en el período 1981-2012 fue de 1,561. El año con mayor registro fue $1983(n=124)$ y el mínimo en $2012(n=7)$. El promedio por año fue de 48.78 \pm 27.1 casos registrados por el sistema en el periodo. El estado que mostró mayor promedio de casos por año fue Veracruz con $12.06 \pm 7.8$, seguido por Chiapas $11.56 \pm 11.01$ y Tabasco con $5.31 \pm 7.2$. En el $80.72 \%$ de los casos registrados $(n=1,260)$, no se especifica el serotipo de EV. El $18.78 \%$ de los casos ( $\mathrm{n}=$ 293) corresponden al serotipo NJ y el $0.5 \%$ $(\mathrm{n}=8)$ son del serotipo IN. La relación $\mathrm{NJ}$-IN es de 37 a 1 . Con respecto a la frecuencia de casos totales en el periodo, el $59.3 \%$ se registró en los estados de Veracruz (24.7\%), Chiapas (23.7 \%) y Tabasco (10.9\%) (Figuras 1,2 ). collected between 1982 and 2004 from cattle of the States of Chiapas $(n=15)$, Tabasco $(n=$ 4) and Veracruz $(n=8)$ and were previously sequenced by other authors $(33,34,35)$. For phylogenetic analysis 408 nucleotides that form part of the hyper variable region of the VE virus gene $P$ were used. This region of the genome tends to accumulate a large number of mutations over time, and may reflect what is happening in other parts of the genome, so it has been used in phylogenetic characterization works $(33,34,35)$.

Phylogenetic analysis was conducted with the software MEGA-5.03(36). Phylogenetic reconstruction parameters include maximum likelihood as a method of phylogenetic reconstruction(37), Tamura of 3 parameters with gamma distribution(38) as a method of nucleotide substitution and 100 replicas of the Bootstrap method were used as statistical support(39). In addition, in order to calculate total genetic diversity and by State, using the software Mega 5.03, paired comparisons

Figura 1. Casos de estomatitis vesicular en México por entidad federativa, 1981-2012

Figure 1. Cases of vesicular stomatitis in Mexico 1981-2012

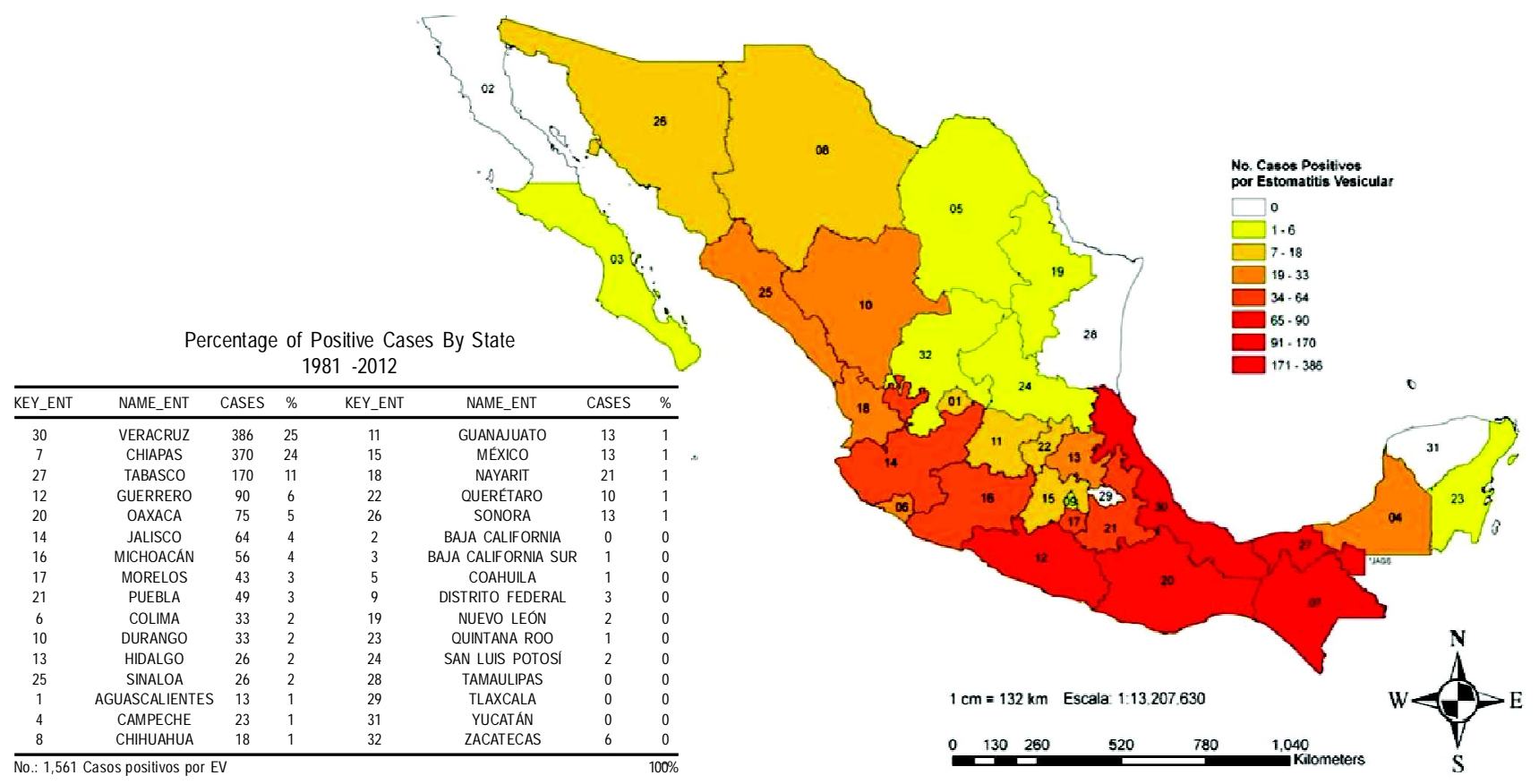


Figura 2. Proporción anual de EV/Hato 1/10,000 vs porcentaje de casos positivos. México 1981-2012

Figure 2. Annual rate $1 / 10,000$ of infected herds vs percentage of positive cases. Period 1981-2012

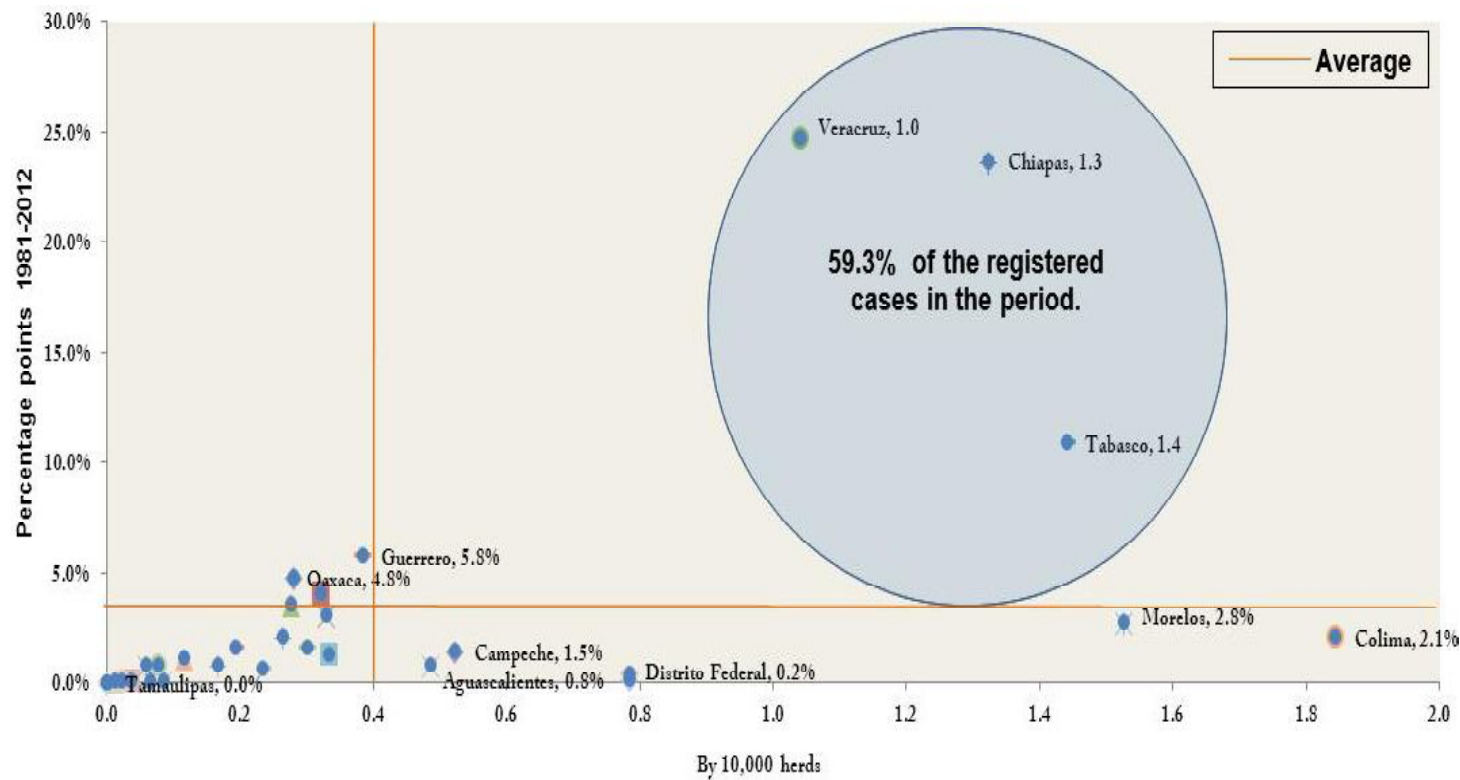

La incidencia de estomatitis vesicular (IEV) a nivel nacional en este periodo fue de 0.163 \pm 0.212 por 100 mil bovinos. Para Chiapas fue de $0.469 \pm 0.45$, Tabasco $0.330 \pm 0.42$ y Veracruz $0.304 \pm 0.20$ por 100 mil bovinos (Cuadro 2).

La proporción de casos de EV por 10 mil hatos (PCEV/10 mil hatos) fue muy variable en el país, detectando una mayor PCEV para estados con pocos hatos ganaderos como el estado de Morelos, que tuvo una proporción 1.5/10 mil hatos (DE \pm 2.9 ), o Colima, con 1.8/10 mil hatos (DE \pm 4.3). Para los estados de Chiapas, Tabasco y Veracruz, que presentan casos de EV todos los años y tienen una alta densidad ganadera, la proporción fue de $1.3 \pm 1.3$; 1.4 \pm 2.0 y $1.0 \pm 0.7$ respectivamente (Figura 2 , Cuadro 3).

Al contrastar los porcentajes de casos por entidad federativa, contra la PCEV/10 mil hatos, sobresalen los estados de Veracruz, Chiapas, Tabasco, y en menor medida, pero por arriba de los promedios, el estado de Guerrero, indicando las zonas de mayor actividad viral between sequences were realized taking into account the number of nucleotide differences.

\section{RESULTS}

1981-2012 information analysis

The total confirmed VE cases in the period 1981-2012 was 1,561. The year with the highest record was $1983(n=124)$ and the minimum in $2012(n=7)$. The average per year was 48.78 \pm 27.1 . The State that showed higher average cases per year was Veracruz with $12.06 \pm 7.8$, followed by Chiapas $11.56 \pm 11.01$ and Tabasco with $5.31 \pm 7.2$. In $80.72 \%$ of the registered VE cases $(n=1,260)$ did not be serotype specific. The $18.78 \%$ of the cases $(n=293)$ correspond to the $\mathrm{NJ}$ serotype and $0.5 \%$ ( $\mathrm{n}=$ 8) were IN serotype. $\mathrm{NJ}-\mathrm{IN}$ relationship is 37 to 1 . Regarding the frequency of total cases in the period, $59.3 \%$ were recorded in the States of Veracruz (24.7\%), Chiapas (23.7\%) and Tabasco (10.9\%) (Figures 1, 2).

The incidence of vesicular stomatitis (IVE) at national level in this period was $0.163 \pm 0.212$ 
Roberto Navarro López, et al. / Rev Mex Cienc Pecu 2015;6(3):277-294

(Figura 2). Estados con altas densidades de ganado bovino como Jalisco, Chihuahua y Sonora, se localizan por debajo del $5 \%$ de los porcentajes de presentación y con proporciones

Cuadro 2. Incidencia de estomatitis vesicular media anual por Estado por 100 mil bovinos durante el periodo de 1981 a 2012

Table 2. Average annual incidence of vesicular stomatitis by State per 100,000 bovines during the period 19812012

\begin{tabular}{lcc}
\hline State & Strategic indicator & Standard deviation \\
\hline Morelos & 0.865 & 1.390 \\
Distrito Federal & 0.677 & 3.225 \\
Colima & 0.507 & 1.082 \\
Chiapas & 0.469 & 0.458 \\
Tabasco & 0.330 & 0.428 \\
Aguascalientes & 0.311 & 0.972 \\
Veracruz & 0.304 & 0.201 \\
Guerrero & 0.250 & 0.399 \\
Puebla & 0.217 & 0.258 \\
Hidalgo & 0.167 & 0.261 \\
Oaxaca & 0.155 & 0.229 \\
Querétaro & 0.136 & 0.482 \\
Campeche & 0.117 & 0.421 \\
Michoacán & 0.112 & 0.276 \\
Durango & 0.089 & 0.254 \\
Nayarit & 0.085 & 0.267 \\
Estado de México & 0.074 & 0.182 \\
Jalisco & 0.069 & 0.177 \\
Sinaloa & 0.062 & 0.191 \\
Guanajuato & 0.046 & 0.153 \\
Chihuahua & 0.031 & 0.058 \\
Quintan Roo & 0.027 & 0.152 \\
Sonora & 0.022 & 0.060 \\
Baja California Sur & 0.019 & 0.109 \\
Zacatecas & 0.019 & 0.062 \\
Nuevo León & 0.012 & 0.048 \\
Coahuila & 0.008 & 0.043 \\
San Luis Potosí & 0.007 & 0.029 \\
Yucatán & 0.000 & 0.000 \\
Tlaxcala & 0.000 & 0.000 \\
Tamaulipas & 0.000 & 0.000 \\
Baja California & 0.000 & 0.000 \\
TOTAL & 0.163 & 0.212 \\
\hline & &
\end{tabular}

per 100 thousand bovines. Chiapas was 0.469 \pm 0.45 , Tabasco $0.330 \pm 0.42$ and Veracruz $0.304 \pm 0.20$ per 100 thousand cattle (Table 2).

The proportion of cases of VE per 10 thousand herds (PCEV/10 th) was very variable in the

Cuadro 3. Proporción de casos de estomatitis vesicular por 10 mil hatos por Estado en el periodo 1981 a 2012 Table 3. Proportion of cases of vesicular stomatitis per 10,000 herds by State in the period 1981 to 2012

\begin{tabular}{lcc}
\hline State & Strategic indicator & Standard deviation \\
\hline Colima & 1.8 & 4.3 \\
Morelos & 1.5 & 2.9 \\
Tabasco & 1.4 & 2.0 \\
Chiapas & 1.3 & 1.3 \\
Veracruz & 1.0 & 0.7 \\
Distrito Federal & 0.8 & 2.5 \\
Campeche & 0.5 & 2.0 \\
Aguascalientes & 0.5 & 1.9 \\
Guerrero & 0.4 & 0.6 \\
Nayarit & 0.3 & 1.1 \\
Puebla & 0.3 & 0.4 \\
Jalisco & 0.3 & 0.9 \\
Sinaloa & 0.3 & 1.0 \\
Oaxaca & 0.3 & 0.4 \\
Michoacán & 0.3 & 0.7 \\
Durango & 0.3 & 0.7 \\
Querétaro & 0.2 & 0.8 \\
Hidalgo & 0.2 & 0.3 \\
Sonora & 0.2 & 0.5 \\
Chihuahua & 0.1 & 0.2 \\
Quintana Roo & 0.1 & 0.5 \\
Guanajuato & 0.1 & 0.3 \\
Baja California Sur & 0.1 & 0.4 \\
México & 0.1 & 0.1 \\
Zacatecas & 0.0 & 0.1 \\
Nuevo León & 0.0 & 0.1 \\
Coahuila & 0.0 & 0.1 \\
San Luis Potosí & 0.0 & 0.1 \\
Baja California & 0.0 & 0.0 \\
Tamaulipas & 0.0 & 0.0 \\
Tlaxcala & 0.0 & 0.0 \\
Yucatán & 0.0 & \\
\hline & & \\
\hline
\end{tabular}


de morbilidad menores al $0.4 / 10$ mil hatos. Estados como Colima y Morelos presentan proporciones superiores a Tabasco, Chiapas y Veracruz, pero también por debajo del porcentaje de presentación del $5 \%$.

La especie más afectada por su frecuencia, fue la bovina con el $91 \%$ de los casos, siguiendo en orden de importancia los ovinos, porcinos, equinos y caprinos. Con respecto a la temporalidad, la presencia de casos es directamente proporcional al ciclo de lluvias en México (mayo - octubre) (Figura 3). El pico de casos de EV se registra en el mes de octubre, con 276 casos en los períodos descritos.

Al analizar el comportamiento de la enfermedad en el tiempo y el espacio, se detectó un ciclo de presentación anual para los estados de Chiapas, Veracruz y Tabasco, afectando municipios aledaños de los estados de Oaxaca, Puebla y Campeche (Figura 4). Es posible la existencia de una zona endémica en el estado de Guerrero con influencia en municipios de los estados de Michoacán, oeste y costa de Oaxaca, Morelos y sur de Puebla. A nivel municipal, los municipios con mayor actividad viral en el tiempo y el espacio, corresponden a los ubicados en la zona central de Chiapas, los límites de Tabasco con Chiapas y el sur de Veracruz. De igual forma, sobresalen los municipios de los límites de Tabasco y Chiapas con la región del Petén en Guatemala.

Cuando se analizaron los casos de la zona endémica (Veracruz, Chiapas y Tabasco) en relación a los tipos de clima y precipitación pluvial, se observó que el período de menos casos de EV, corresponde a la temporada más seca del año, que es abril, con el $3 \%$ (Figura 3). Conforme inicia el período de lluvias en mayo, se registra un incremento de casos, que continúa hasta alcanzar el máximo en el mes de octubre, con el $21 \%$, disminuyendo conforme el temporal de lluvias decrece. Para octubre, el $80 \%$ del agua de lluvia ha caído, y se detectan diferencias en el acumulado de casos de EV por tipo de clima: en el clima Af, $68.9 \%$ de los country, sensing a greater PCEV to States with few livestock herds as the state of Morelos, which had a ratio of $1.5 \pm 2.9 / 10$ th, or Colima, with $1.8 \pm 4.3 / 10$ th. For the states of Chiapas, Tabasco and Veracruz with a high livestock density, and VE cases every year presented ratios of $1.3 \pm 1.3 ; 1.4 \pm 2.0$ and $1.0 \pm 0.7$ respectively (Figure 2 , Table 3 ) .

To compare the percentages of cases by State, against the PCEV/10 th, highlight the states of Veracruz, Chiapas, Tabasco, and to a lesser extent, but above the average, the state of Guerrero, indicating the areas of increased viral activity (Figure 2). States with high cattle densities as J alisco, Chihuahua and Sonora, are below $5 \%$ of presentation and morbidity ratios of less than 0.4/10 th. States of Colima and Morelos have ratios above Tabasco, Chiapas and Veracruz, but also below the $5 \%$ of presentation.

The species most affected by its frequency, were the bovine with $91 \%$ of the cases, following in order of importance sheep, pigs, horses and goats. With respect to temporality, the presence of cases is directly proportional to the rains cycles in Mexico (May - October) (Figure 3).

Figura 3. Distribución porcentual mensual de casos positivos de EV en la zona endémica por tipo de clima (1981-2012)

Figura 3. Monthly percentage distribution of positive cases of VS in the endemic zone by type of climate (1981-2012)

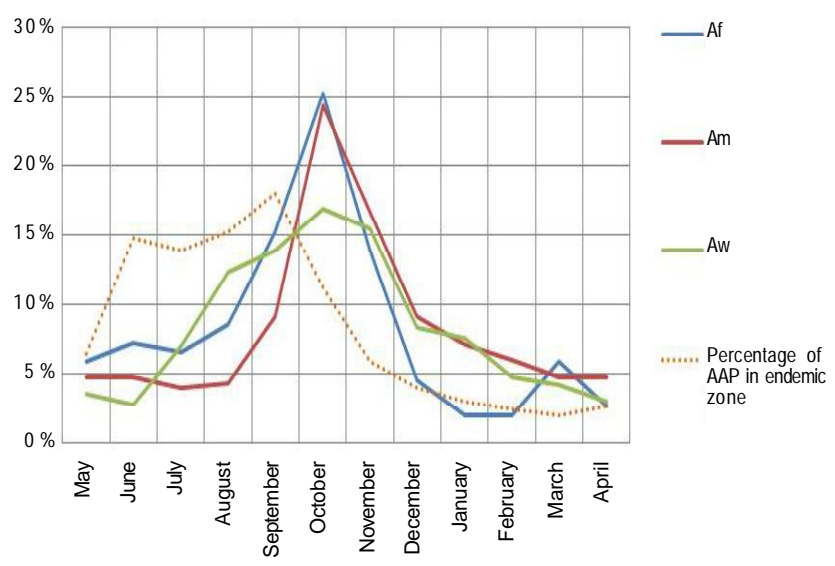


casos se registraron al término del período de lluvias, en el clima Am, el $56.6 \%$ y en el Aw $51.4 \%$.

En el Proyecto Agricultural Research Service United States Department of Agriculture (ARS USDA) y CPA-SENASICA en el año 2003 se registraron 207 investigaciones confirmadas con la identificación del virus de EV, con un promedio de 310 animales por investigación. Por las técnicas de fijación de complemento y aislamiento viral se confirmó la presencia del serotipo NJ en 545 animales, de una población de 6,495 en riesgo (0.8\%). En los 545 animales con lesiones vesiculares, se encontraron un total de 627 lesiones. El 56 \% correspondió a la boca, incluyendo la lengua, encías y labios. La segunda lesión en importancia se localizó en los pezones. El mayor número de animales con lesiones vesiculares encontradas correspondió al clima Aw con el $53.9 \%$, siguiendo en importancia el clima Am con $32.1 \%$ y Af con $13.9 \%$. A nivel serológico, durante la investigación de campo, se recuperó suero
October was the month with a peak of $276 \mathrm{VE}$ cases, in the periods described.

In an analysis of the disease in time and space, the states of Chiapas, Veracruz and Tabasco, had an annual cycle, affecting surrounding municipalities of the states of Oaxaca, Puebla and Campeche (Figure 4). It is possible the existence of an endemic area in the state of Guerrero with influence in municipalities of the states of Michoacán, Western and coast of Oaxaca, Morelos and South of Puebla. At the municipal level, the municipalities with increased viral activity in time and space, are those located in the central area of Chiapas, southern Veracruz and borders of Tabasco with Chiapas. Similarly, outstanding municipalities of Tabasco and Chiapas limits with the region of the Petén in Guatemala.

When analyzing cases of the endemic zone (Veracruz, Chiapas and Tabasco) in relation to the types of climate and rainfall, it was observed that the period of fewer VE cases, corresponds

Figura 4. Distribución geográfica por municipio en las zonas endémicas de México, 1981-2012

Figura 4. Geografic distribution of endemic zones per municipality, 1981-2012

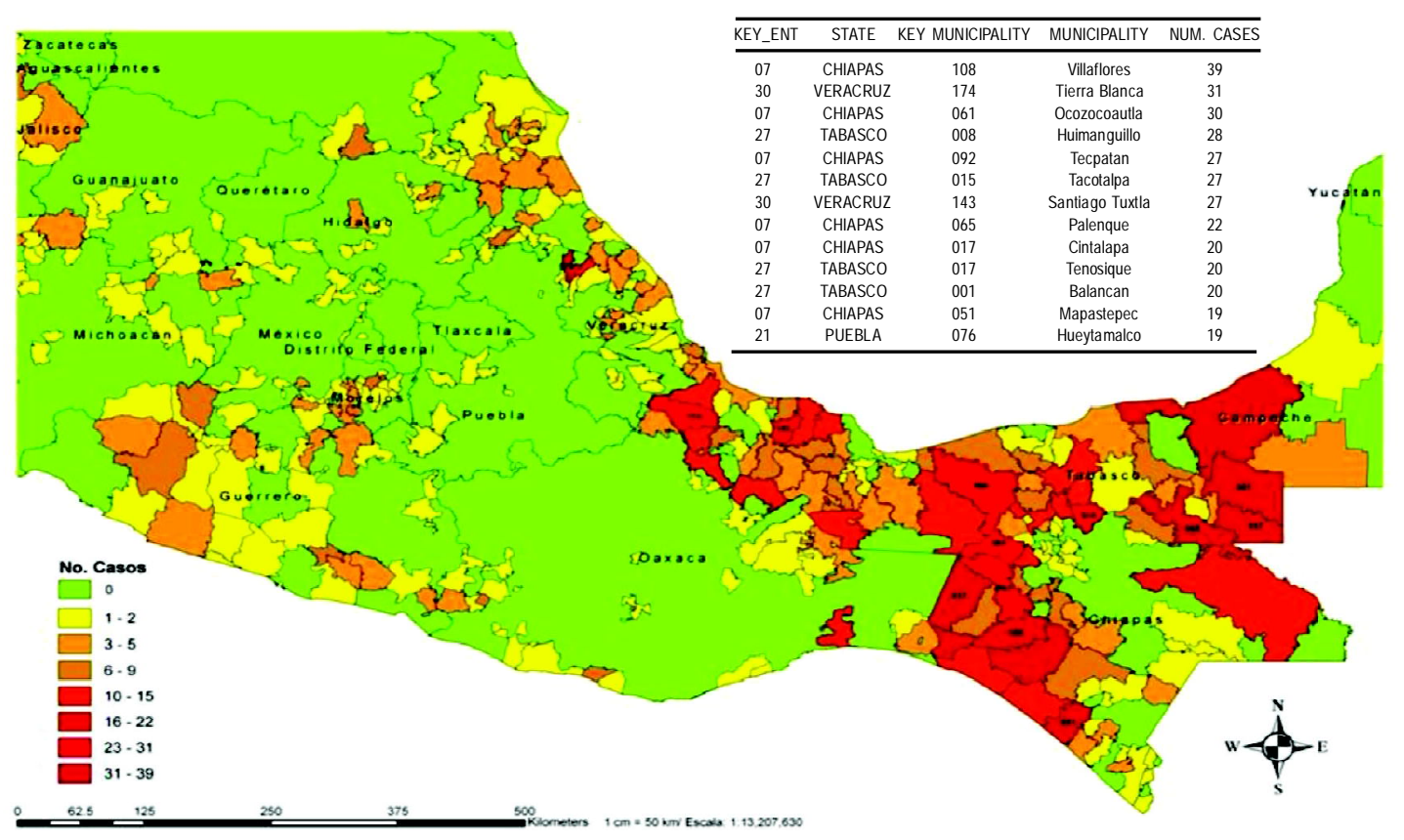


sanguíneo a 480 animales infectados clínicamente de EV. La prueba de seroneutralización demostró que el $62.3 \%$ tenía anticuerpos neutralizantes contra EV del serotipo Nueva Jersey (T 1:801:2560), el serotipo Indiana el $0.4 \%$ ( $T$ 1:10$1: 320)$ y el $25.2 \%$ contra ambos serotipos Nueva Jersey e Indiana; el $9.5 \%$ resultaron negativos.

\section{Diversidad Genética}

La diversidad nucleotídica del virus de estomatitis vesicular Nueva J ersey en México fue estimada sobre $4 \%$. Valores similares fueron encontrados para cada uno de los tres estados. Esta alta diversidad nucleotídica de correlación se muestra en la Figura 5, donde fue posible distinguir la presencia de por lo menos nueve diferentes to the dry season, which is April, with $3 \%$ (Figure 3). As the rainy season begins in May, there is a rise of cases, which continue until reaching its maximum in October, with $21 \%$, decreasing as the temporal rainfall decreases. For October, $80 \%$ of rain water has fallen, and differences in the cumulative cases of VE by type of climate are detected. In climate Af, $68.9 \%$ of the cases were registered at the end of the rainy season, in Am $56.6 \%$ and in the Aw $51.4 \%$.

In the project Agricultural Research Service United States Department of Agriculture (ARS USDA) and CPA-SENASICA in 2003 there were 207 investigations confirmed with the identification of the VE virus, with an average of 310 animals per research. Complement

Figura 5. Análisis filogenético por el método de máxima verosimilitud y utilizando 408 nucleótidos de la región hipervariable del virus de estomatitis vesicular Nueva Jersey

Figure 5. Phylogenetic analysis by maximum likelihood with 408 nucleotids of the hyphervariable region of the vesicular stomatitis virus serotype Nueva Jersey

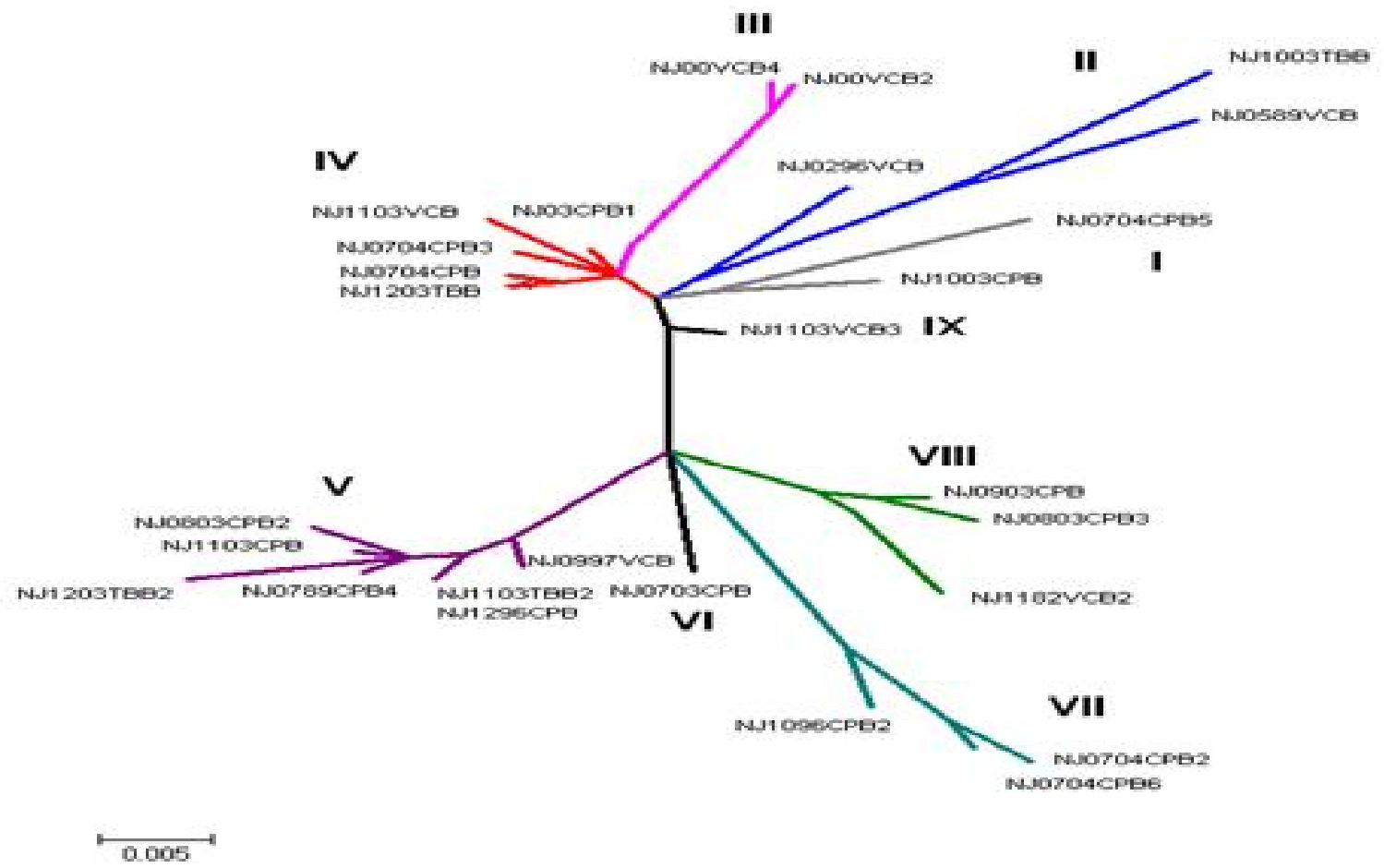

Nomenclature: $\mathrm{NJ}=$ Nueva Jersey; numbers correspond to month ans year of isolation; $\mathrm{CP}=\mathrm{Chiapas} ; \mathrm{TB}=\mathrm{Tabasco}$; $\mathrm{VC}=$ Veracruz. 
linajes virales, los cuales circulan en Chiapas, Veracruz y Tabasco. Asimismo, fue posible estimar el tiempo que algunos de estos linajes han estado circulando; por ejemplo, en el linaje número VIII se agrupan las secuencias NJ 1182VCB2 (recuperada en Veracruz en 1982) con las secuencias NJ 0903CPB y NJ 0803CPB3 (recuperadas en Chiapas en 2003) con una diferencia entre ellas en el tiempo de aislamiento de 21 años. Otros ejemplos son las secuencias de linaje II NJ0589VCB con la secuencia NJ 1003TBB, y las secuencias del linaje $V$ NJ 1103TBB2 y NJ 0789CB4, en estos casos con 14 años de diferencia. Estos resultados indican que estos virus han logrado establecerse en diferentes nichos ecológicos en los estados de Chiapas, Tabasco y Veracruz y que mantienen una gran estabilidad genética, siendo responsables de la presentación de casos anualmente.

\section{DISCUSIÓN}

Los resultados muestran que el serotipo $\mathrm{NJ}$ se mantiene secularmente de manera endémica con una estabilidad genética en nichos ecológicos de municipios de los estados de Chiapas, Veracruz y Tabasco. Estos municipios se ubican en el trópico húmedo, con climas Af y Am y en trópico seco Aw. Esta situación es similar a la encontrada por otros autores para zonas ecológicas de trópico seco Aw, donde se demuestra estabilidad genética de más de 30 años(2). La manifestación clínica generalmente se considera benigna dentro de las zonas endémicas, con una incidencia menor al $1 \%$. Esto parece ser consecuencia a la exposición constante al virus, que ocasiona infecciones subclínicas, que se reflejan en los estudios serológicos(7). El análisis de la información epidemiológica en México hace evidente que cuando se presentan casos de EV en los estados limítrofes con la unión americana, como son Sonora, Chihuahua, Coahuila y Nuevo León, se presentan también brotes en los EUA en un ciclo de 5 a 10 años $(6,12,34)$.

Se pueden presentar brotes explosivos, muy localizados dentro de las zonas endémicas en fixation and virus isolation techniques confirmed the presence of the $\mathrm{NJ}$ serotype in 545 animals, from a population of 6,495 at risk $(0.8 \%)$. A total of 627 lesions were found in the 545 animals with vesicular lesions. Fifty six (56) \% corresponded to the mouth, including the tongue, gums and lips; the second important injury was located in the nipples. The greatest number of animals with vesicular lesions encountered corresponded to clime Aw with the $53.9 \%$, following in importance the clime Am with $32.1 \%$ and Af with $13.9 \%$. Serologically, during the field research, blood serum from 480 VE clinically infected animals were recovered. The serum neutralization test showed that the $62.3 \%$ had neutralizing antibodies against VE of serotype New Jersey (T 1:80-1:2560), serotype Indiana $0.4 \%$ ( $\mathrm{T}$ 1:10-1:320) and $25.2 \%$ against both New Jersey and Indiana serotypes; $9.5 \%$ were negative.

\section{Genetic diversity}

Nucleotide diversity of the vesicular stomatitis by the New J ersey virus in Mexico was estimated to be about $4 \%$. Similar values were found for each of the three states. This high correlation of nucleotide diversity is shown in Figure 5, where it was possible to distinguish the presence of at least nine different viral lineages, which circulate in Chiapas, Veracruz and Tabasco. Furthermore, it was possible to estimate the time that some of these lineages have been circulating; for example, in the lineage number VIII are grouped sequences NJ 1182VCB2 (retrieved at Veracruz in 1982) with the sequences NJ0903CPB and NJ0803CPB3 (recovered in Chiapas in 2003) with a difference between them at the time of isolation of $21 \mathrm{yr}$. Other examples are Lineage II NJ 0589VCB with string NJ 1003TBB sequences, and sequences of lineage V NJ 1103TBB2 and NJ0789CB4, in this case $14 \mathrm{yr}$ apart. These results indicate that these viruses have managed to settle in different ecological niches in the states of Chiapas, Tabasco and Veracruz and that maintains a high genetic stability, being responsible for the annually presentation of cases. 
explotaciones tecnificadas de cerdos y bovinos estabulados, que deben alertar al sistema de vigilancia. Esta población, posiblemente no está expuesta al virus, como lo están los animales de libre pastoreo. Como ejemplo, en la región de Villaflores, Chiapas, en donde está plenamente demostrada la actividad viral(7), se comprobó un brote de EV-NJ en una explotación de cerdos integrada y tecnificada, afectando a más del $90 \%$ de los animales; este brote se asoció a la presencia de bovinos dentro de las unidades de producción, lo cual ocasionó severas pérdidas económicas. Esto es importante estudiar, debido a que los insectos transmisores posiblemente son atraídos por los bovinos(40); esto es factible, ya que después de que fueron retirados los bovinos, no se han presentado nuevos casos en más de 15 años.

En 2003, se confirmaron dos brotes de EV-NJ en cerdos de traspatio en los municipios de Minatitlán, Veracruz y Comalcalco, Tabasco; a los animales infectados se les tomó, además de los epitelios, muestra de sangre, presentando títulos neutralizantes para los dos serotipos $\mathrm{NJ}$ (T 1:280) e IN (T 1:20-1:360). Fuera de la zona endémica, en el norte del país, en el municipio de Navojoa, Sonora, región lejana a las zonas endémicas, en el año 2009 se presentó un brote en una granja tecnificada de porcinos por el serotipo NJ confirmado por aislamiento viral en ratón lactante. La población era de 4,174 animales, y al momento de la investigación había 200 enfermos con vesículas en diferentes partes del cuerpo y 10 muertos por causa desconocida. Los anticuerpos neutralizantes en seis animales afectados clínicamente tuvieron un título de 1:1024 al serotipo NJ .

Los datos serológicos que se presentan, obtenidos en el período 1981-2012, demuestran que los animales clínicamente afectados con vesículas y confirmada la enfermedad, tenían anticuerpos neutralizantes en un $62.3 \%$, contrastante con otros artículos que refieren que esta serología oscila entre el 9 a $11 \%(2)$.

Los estudios de comportamiento epidemiológico de esta enfermedad en los diferentes países

\section{DISCUSSION}

The results show that the $\mathrm{NJ}$ serotype is maintained endemic regularly with genetic stability in ecological niches of municipalities in the states of Chiapas, Veracruz and Tabasco. These municipalities are located in the humid tropics, with Af and Am climates and tropical dry Aw. This situation is similar to that found by other authors for Aw dry tropical ecological zones, where it shows genetic stability of more than $30 \mathrm{yr}(2)$. The clinical manifestation is generally considered benign in endemic areas, with an incidence of less than $1 \%$. This seems to be due to constant exposure to the virus that causes subclinical infections, reflected in serological studies(7). The analysis of epidemiological information in Mexico evidences that when VE cases are presented in Mexican States bordering the United States, such as Sonora, Chihuahua, Coahuila and Nuevo Leon, outbreaks arise also in the United States within a 5 to $10 \mathrm{yr}$ cycle(6,12,34).

Explosive, much localized outbreaks can occur in endemic areas in technified confined farms of pigs and cattle, which should alert the monitoring system. This population may not be possibly exposed to the virus, as they are freegrazing animals. As an example, in the region of Villaflores, Chiapas, where the viral activity is fully demonstrated (7), it was found an outbreak of VE-NJ on a technified and integrated pig exploitation, affecting more than $90 \%$ of the animals. This outbreak was associated to the presence of cattle within the production units, which caused severe economic loss. Cases like this are important for research, since transmitters insects are possibly attracted by

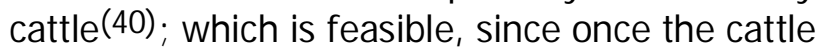
were removed, there have been no new cases for over $15 \mathrm{yr}$.

In 2003, two outbreaks of VE-NJ were confirmed in pig's backyards in the municipalities of Minatitlán, Veracruz, and Comalcalco, Tabasco; in infected animals, in addition to epithelium samples, blood sample presented neutralizing 
donde se manifiesta de manera endémica, coinciden con el presente estudio, donde los casos clínicos y subclínicos están asociados a la presencia permanente del agente infeccioso, el clima tropical húmedo o seco (Aw, Af y Am), la presencia de vectores y el estado inmunitario de los animales. Un factor de riesgo lo representan los insectos hematófagos, debido a su demostrada participación en la transmisión de la enfermedad, principalmente en la época de lluvias donde incrementan su población, por lo que se ha recomendado el baño insecticida y repelente cuando se presentan casos o brotes confirmados de EV, aunado a restricciones para impedir la movilización de animales clínicamente afectados(2). A nivel espacial, se consideró en 1978(41) que las áreas endémicas se encontraban en los llanos costeros alrededor de Veracruz y a lo largo del bajo Istmo de Tehuantepec, y aunque se reconocía que en los estados de Chiapas, Tabasco y sur de Veracruz se mantenía el virus de la EV, el presente estudio lo comprueba a nivel de municipio y tipo de clima, encontrando aún dentro de estos estados, áreas libres de la enfermedad (Figura 4).

No obstante que las pérdidas económicas pudieran ser significativas dentro de las áreas endémicas a causa de la EV, normalmente no genera en los productores ganaderos una preocupación permanente por esta enfermedad, por tanto, no se notifican los casos de EV. Esto puede ser la causa de que no se hayan realizado estudios formales en México para cuantificar su impacto, por pérdidas de leche y peso, o por tratamiento de animales infectados. En los EUA se considera que la EV es económicamente muy importante, principalmente por la restricción en la movilización de equinos $(6,33)$.

Debido a la gran capacidad de difusión y destrucción del virus de la FA, presente en algunos países sudamericanos y otras regiones del mundo, se ha establecido un programa de detección temprana de FA tomando como base la investigación inmediata de casos de enfermedad vesicular, representada en México exclusivamente por la EV. El presente trabajo titles for the two serotypes IN (1:280 T) and NJ (T 1:20-1:360). Outside the endemic zone, in the North of the country, in the municipality of Navojoa, Sonora, region far to endemic areas, in 2009 an outbreak in a technified farm of pigs was confirmed by virus isolation of $\mathrm{NJ}$ serotype in suckling mice; with a population of 4,174 animals at the time of research, there were 200 patients with vesicles in different parts of the body and 10 deaths by unknown causes. Neutralizing antibodies in six clinically affected animals had a titer of 1:1024 to the NJ serotype.

Serological data presented, obtained in the period 1981-2012, demonstrate that clinically affected animals with vesicles and the disease confirmed, had $62.3 \%$ neutralizing antibodies, contrasting with other information referring that this serology oscillates between 9 and $11 \%(2)$.

Studies of epidemiological behavior in countries where the disease is endemic coincide with the present study, where clinical and subclinical cases are associated with the permanent presence of the infectious agent, humid or dry tropical climate (Aw, Af and Am), the presence of vectors and the immune status of the animals. The blood-sucking insects, because of their proven participation in the transmission of the disease, mainly in the rainy season where its population increase, represent a risk factor. Insecticide and repellent bath are recommended in cases or confirmed outbreaks of VE, coupled with restrictions to prevent the mobilization of clinically affected animals(2). In 1978(41) endemic areas were showed in the coastal plains around Veracruz and along the low isthmus of Tehuantepec; and although it was recognized the presence of the virus in the states of Chiapas, Tabasco and southern Veracruz, the present study evidenced it at the municipality level and type of climate, finding even within these states, free areas of the disease (Figure 4).

Although economic losses could be significant within VE endemic areas, normally do not generated permanent concerns in the farmers 
señala con claridad los lugares donde la EV es endémica en México y la frecuencia en la que se ha presentado en latitudes fuera de las zonas endémicas.

Por su importancia, se debe mantener y mejorar la vigilancia de la EV para detectar en tiempo y forma, posibles casos de FA u otra enfermedad exótica. Para ello se requiere de indicadores, que son las herramientas para clarificar y definir, de forma más precisa, objetivos e impactos de un programa, en este caso de las enfermedades vesiculares. En este estudio, se construyeron dos indicadores estratégicos, como es la IEV/ 100 mil bovinos y la PCEV/10 mil hatos por entidad federativa (Cuadros 2, 3), que constituyen elementos necesarios para la construcción de la Matriz de Indicadores para Resultados en los programas oficiales, que pueden servir como línea base para los servicios veterinarios oficiales responsables de esta vigilancia.

Además de que la EV puede ser confundida con FA, la EV ha sido considerada de importancia para el comercio, especialmente de equinos, donde aparentemente se difundió el virus por movilización de caballos de Norteamérica a Europa durante la primera guerra mundial. La Unión Europea ha elaborado estudios, que en teoría, explican como un virus de EV pudiera eventualmente llegar a Europa y diseminarse $(5,42)$. Ante este escenario, en 2012 se generó un debate en la OIE para retirar a la EV de la lista de las enfermedades limitantes del comercio internacional(43). En la reunión anual de la OIE de 2013 fue un tema de debate(44) y se consolidó su retiro con la publicación del Código de los Animales Terrestres 2014(4).

\section{CONCLUSIONES E IMPLICACIONES}

Al crear un indicador basado en la IEV o la PCEV-hato, se tiene una medida verificable de cambio o resultado, diseñada para contar con un estándar contra el cual evaluar, estimar o demostrar el progreso del sistema de vigilancia for this disease, therefore, VE cases go unreported. This could be the reason for the lack of formal studies in Mexico to quantify its impact, milk and weight loss, or by treatment of infected animals. In the United States VE is considered economically very important, mainly due to the restriction on the mobilization of equines $(6,33)$.

Due to the large capacity of dissemination and destruction of the FMD virus, present in some South American countries and other regions of the world, it has been established a program of early FMD detection on the basis of the immediate investigation of vesicular disease cases, represented in Mexico exclusively by the VE. This paper clearly indicates areas where the VE is endemic in Mexico and the frequency in which has been presented at latitudes outside endemic areas.

Because of its importance, it must maintain and improve VE surveillance to detect in time and form, possible cases of MFD or other exotic disease. This requires indicators, tools to clarify and define more precisely, objectives and impacts of a program, in this case of vesicular diseases. In this study, two strategic indicators, were built as the IVE/100 thousand cattle and PCEV/ 10 thousand herds by State (Tables 2, 3), key elements for the construction of the outcome indicator matrix, which can serve as baseline for the official veterinary services responsible for this surveillance.

In addition that the VE can be confused with MFD, it has been considered important for trade, especially in horses, where apparently the virus was spread by mobilization of horses from North America to Europe during the First World War. The European Union has developed studies, which in theory, explained how a VE virus could eventually reach Europe and then spread $(5,42)$. Given this scenario, a VE debate was generated at the OIE to withdraw it from the list of diseases limiting international trade(43). At the annual meeting of the OIE in 2013 was a topic of discussion(44) and consolidated his retirement 
con respecto a metas establecidas, facilitando además, el reparto de insumos, produciendo productos y alcanzando objetivos que pueden servir entre otras cosas para estudios de regionalización y análisis de riesgo. Cabe recordar que todos los programas sociales, como es el caso de la vigilancia de las enfermedades animales, requieren de la construcción de una MIR. Los indicadores que se proponen, son específicos, porque se encuentran perfectamente vinculados al problema, explícitos, porque están utilizando la incidencia y la proporción, y relevantes por sus implicaciones al comercio y la economía. Sin embargo, análisis posteriores a su utilización serán necesarios para su valoración. Es posible que a través de los años, al intensificarse y tecnificarse la producción en las zonas endémicas de EV, se registren brotes con cuantiosas pérdidas de producción sobre todo en explotaciones lecheras y de producción porcina, que además deben ser investigados para descartar que se trata de FA. Adicionalmente, nos enfrentamos a un fenómeno de cambio climático mundial que puede favorecer la expansión de los artrópodos vectores y el movimiento o amplitud de las zonas endémicas reconocidas en este estudio.

\section{LITERATURA CITADA}

1. SAGARPA. Secretaría de Agricultura, Ganadería, Desarrollo Rural, Pesca y Alimentación. Acuerdo mediante el cual se enlistan las enfermedades y plagas de los animales, exóticas y endémicas de notificación obligatoria en los Estados Unidos Mexicanos. Diario Oficial de la Federación. México. 2007.

2. Rodríguez LL. Emergence and re-emergence of vesicular stomatitis in the United States. Virus Res 2002;85(2):211219. doi: 10.1016/S0168-1702(02)00026-6.

3. Bridges VE, McCluskey BJ, Salman MD, Hurd HS, Dick J. Review of the 1995 vesicular stomatitis outbreak in the western United States. J Am Vet Med Assoc 1997;211:556560.

4. OIE. Organización Mundial de Sanidad Animal. Código sanitario de los animales terrestres. Recomendaciones aplicables a las enfermedades de la lista de la OIE y a otras enfermedades importantes para el comercio internacional. 23ạ ed. Francia. 2014. ISBN Vol. II 978-92-9044-941-6. http://www.oie.int/es/normas-internacionales/codigoterrestre/acceso-en-linea/. with the publication in 2014, of the Terrestrial Code for Animals(4).

\section{CONCLUSIONS AND IMPLICATIONS}

By generating an indicator based on the IVE or PCEV-herd, there are a verifiable measurement for change or result, designed to provide a standard against which to evaluate, estimate or demonstrate the progress of the surveillance system with respect to goals; facilitating also the distribution of inputs, producing products and reaching goals that can serve among other things to regionalization and risk analysis. It should be recalled that all social programs, as it is the case of the animal disease surveillance, require the construction of an $\mathrm{OIM}$. The indicators that are proposed, are specific, because they are perfectly linked to the problem, explicit, because they are using the incidence and proportion, and relevant by its implications to trade and the economy. However, subsequent use of analysis will be needed for their evaluation. It is possible that over the years, intensified and modernized animal production in the VE endemic areas, cause outbreaks with massive losses of production, mostly in dairy farms and pig production units, which should also be investigated to rule out that it is not MFD. In addition, the global climate change phenomenon may favor the expansion of arthropod vectors and movement or amplitude of the endemic areas recognized in this study.

\section{End of english version}

5. EFSA. European Food Safety Authority. Scientific opinion on swine vesicular disease and vesicular stomatitis. EFSA J 2012;10(4):2631.

6. Rodríguez LL. Vesicular stomatitis. USAHA Foreign animal diseases. Boca Publications Group, Inc. 7th ed. Boca Ratón, USA. 2008:423-429. ISBN 978-0-96595 83-4-9.

7. Adell AA, Pérez AM, Navarro LR, López GI, Paz RP, Rodríguez $\mathrm{LL}$. Estimation of the time of seroconversion to the New Jersey serotype of vesicular stomatitis virus in sentinel cattle of dairy herds located at high and low elevations in southern Mexico. AJ VR. 2010; 71(12):1-6. 
8. Hanson RP. The natural history of vesicular stomatitis. Bacteriol Rev 1952; 16: 179-204.

9. Brooksby JB. Differential diagnosis of vesicular stomatitis and foot and mouth disease, examination of virus samples from Mexico with especial reference to complement fixation. J Hyg 1949;47(4):384-389.

10. Mexico-United States Commission for the Prevention of Foot-and-Mouth Disease. Proc Inter Conf Vesicular Stomatitis. México. 1984.

11. Arroyo M, Perez AM, Rodríguez LL. Characterization of the temporal and spatial distribution and reproductive ratio of vesicular stomatitis outbreaks in México in 2008. Am J Vet Res 2011;72(2):233-238.

12. Vázquez SL, Pauszek SJ, Zarate S, Basurto-Alcántara FJ, Verdugo-Rodríguez A, Pérez AM, et al. Phylogeographic characteristics of vesicular stomatitis New Jersey viruses circulating in Mexico from 2005 to 2011 and their relationship to epidemics in the United States. Virology 2014;449:1724.

13. Perez AM, Pauszek SJ, Jimenez D, Kelley WN, Whedbee Z, Rodríguez LL. Spatial and phylogenetic analysis of vesicular stomatitis virus over-wintering in the United States. Prev Vet Med 2010; 93:258-264.

14. Tesh RB, Chaniotis BN, Johnson KM. Vesicular stomatitis virus (Indiana serotype): transovarial transmission by phlebotomine sand-flies. Science 1972; 175:1477-1479.

15. Shelokov A, Peralta PH. Vesicular stomatitis virus, Indiana type: an arbovirus infection of tropical sandflies and humans. Am J Epidem 1967; 86(1): 149-157.

16. Tesh RB, Chaniotis BN, Peralta PH, Johnson KM. Ecology of viruses isolated from Panamanian Phlebotomine sandflies. Am J trop Med Hyg 1974;23(2):258-269.

17. Mead DG, Gray EW, Noblet R, Murphy MD, Howerth EW, Stallknecht DE. Biological transmission of vesicular stomatitis virus (New Jersey serotype) by Simulium vittatum (Diptera: Simuliidae) to domestic swine (Sus scrofa). J Med Entomol 2004; 41:78-82.

18. CFSPH. IICAB. The Center for Food Segurity \& Public Health. Institute for International Cooperation in Animal Biologics. Vesicular stomatitis. Iowa State University. USA. 2008. http:/ / www.cfsph.iastate.edu/Factsheets/pdfs/ vesicular_stomatitis.pdf. Accessed May 24, 2013.

19. Sudia WD, Fields BN, Calisher $\mathrm{CH}$. The isolation of vesicular stomatitis virus (Indiana strain) and other viruses from mosquitoes in New Mexico 1965. Amer J Epidem 1967; 68:698-602.

20. Letchworth GJ, Rodríguez LL, Barrera DC. Vesicular stomatitis. The Vet J 1999; 157:239-260.

21. OIE. Organismo Mundial de Sanidad Animal. Estomatitis Vesicular. Código Sanitario para los Animales Terrestres. Vol II. 22a ed. Francia. 2013:504-506. ISBN 978-92-9044915-7. www.oie.int/doc/ged/D12826. pdf.

22. Hanson RP, Rasmussen AF, Brandly CA, Brown JW. Human infection with the virus of vesicular stomatitis. J Lab Clin Med 1950;36:754-758.

23. Mason J, Gay GJ. Preliminary report. Vesicular stomatitis field study. Mexico United - States Commission for the Prevention of Food - and - Mouth Disease. Proc Intern Conf Vesicular Stomatitis. La Commission. México. 1984.

24. Smith PF, Howerth EW, Carter D, Gray EW, Noblet R, Smoliga $\mathrm{G}$, et al. Domestic cattle as a non-conventional amplifying host of vesicular stomatitis New Jersey virus. Med Vet Entomol 2011;25(2): 184-191.

25. OIE. Organismo Mundial de Sanidad Animal. AO20 Estomatitis vesicular. Ficha técnica. http://web.oie.int/esp/ maladies/fiches/e_A020.htm. Accessed Jul 4, 2013.

26. SHCP. SFP. Secretaría de Hacienda y Crédito Público. Secretaría de la Función Pública. Consejo Nacional de Evaluación de la Política de Desarrollo Social. Guía para la construcción de la Matriz de Indicadores para Resultados. México. SHCP. 2011. http://www.shcp.gob.mx/EGRESOS/pef/ sed/guíaMIR.pdf. Accessed J un 1, 2013.

27. Jaramillo ACJ. Investigación epidemiológica. En: Tovar SMA editor. Epidemiología veterinaria. México: Manual Moderno; 2010:83-97.

28. INEGI. Instituto Nacional de Estadística y Geografía. Censo Agrícola, Ganadero y Forestal 2007. INEGI. 2013. http:// www3. inegi.org. mx/sistemas/TabuladosBasicos/ Default.aspx?c=17177\&s=est. Consultado J un 8, 2013.

29. Köppen W. Versuch einer Klassification der Klimate, vorzugsweise nach ihren Beziehungen zur Pflanzenwelt. Geographische Zeitschrift. 1900;6. Jahrg, 11. H.:593-611.

30. Kottek M, Grieser J, Beck C, Rudolf B, Rubel F. World Map of the Köppen-Geiger climate classification updated. $\mathrm{E}$ Schweizerbart'sche Verlagsbuchhandlung. 2006; 15(3): 259263. http://docserver.ingentaconnect.com/deliver/connect/ schweiz/09412948/v15n3/s1.pdf ?expires $=1367511549 \&$ $i d=74037549 \&$ titleid $=1292 \&$ accname $=$ Guest + User\&checksum=042B6CFFB72AC0EB8311120F00162288. Accessed May 02, 2013.

31. Servicio Meteorológico Nacional. Conagua. Normales Climatológicas. SMN. CNA. México. 2010. http:// smn.cna.gob. $m x /$ index.php? option $=$ com_content \&view=article\&id=103\&l temid=80. Consultado $\mathrm{Abr}^{-}$29, 2013.

32. SEMARNAT. Secretaría del Medio Ambiente y Recursos Naturales. Consulta Temática. Precipitación mensual (milímetros).SEMARNAT. México. 2012. http://dgeiawf. semarnat.gob.mx:8080/ibi_apps/WFServlet?IBIF_ex= D3_AGUA01_10\&IBIC_user= dgeia_mce\&I BIC_pass = dgeia_mce. Consultado Apr 25, 2013.

33. Rainwater-Lovett K, Kelley W, Rodriguez LL. Molecular epidemiology of vesicular stomatitis New Jersey virus from the 2004-2005 US outbreak indicates a common origin with Mexicans strains. J Virol 2007;88(Pt7):2042-2051

34. Rodriguez LL, Bunch T, Fraire M, Lleweliyn Z. Re-emergence of vesicular stomatitis in the Western United States is associated with distinct viral genetic lineages. Virology 2000; 271: 171-181.

35. Bilsel P, Rowe J, Fitch W, Nichol S. Phosphoprotein and nucleocapsid protein evolution of vesicular stomatitis virus New Jersey. J Virol 1990;64(6):2498-504.

36. Tamura K, Peterson D, Peterson N, Stecher G, Nei M, Kumar $\mathrm{S}$. Molecular evolutionary genetics analysis using Maximum Likelihood Evolutionary Distance, and Maximum Parsimony Methods. Mol Biol Evol 2011;28(10):2731-2739.

37. Tamura K, Nei M, Kumar S. Prospects for inferring very large phylogenies by using the neighbor-joning method. Proc Nat Acad Sci (USA). 2004; 101:11030-11035.

38. Tamura K. Estimation of the number of nucleotide substitutions when there are strong transition-transversion and G + C content biases. Mol Biol Evol 1992;101:1103011035. 
Roberto Navarro López, et al. / Rev Mex Cienc Pecu 2015;6(3):277-294

39. Nei M, Kumar S. Molecular evolution and phylogenetic. New York, USA: Oxford University Press; 2000.

40. Smith PF, Howerth EW, Carter D, Gray EW, Noblet R, Berghaus $\mathrm{R}$, et al. Host predilection and transmissibility of vesicular stomatitis New Jersey virus strains in domestic cattle (Bos taurus) and swine (Sus scrofa). BMC Vet Res 2012; 8: 183.

41. Mason J. La epidemiología de la estomatitis vesicular. Una revisión de la literatura y propuestas para estudios de campo. Bltn Centro Panamericano Fiebre Aftosa. USA. 1978;2930:13-33.
42. Consejo de la Unión Europea. Directiva 2009/156/CE del Consejo. Diario Oficial de la Unión Europea. 23.7.2010:1-24.

43. OIE. Organización Mundial de Sanidad Animal. Informe de la Reunión de la Comisión de las Normas Sanitarias de la OIE para los animales terrestres. Francia. 2012. www.oie.int/ doc/ged/D12157. pdf. Consultado May 17, 2014.

44. Antúnez P. Estomatitis vesicular está en el debate de la OIE. Noticias El País. Uruguay. 2013. http:// www. noticiasuy.com/Noticia/Economia/20130610/ 635063955432271310/Estomatitis_vesicular_esta en_el_debate_de_la_OIE. Consultado May 8, 2014. 